\title{
A Classification Study over Loan Words Used in the Fields of Turkish Literature, Grammar, Linguistics and Pedagogy
}

\author{
Mehmet Alver \\ Department of Turkish Education, Giresun University, Turkey
}

Copyright $\mathrm{C} 2019$ by authors, all rights reserved. Authors agree that this article remains permanently open access under the terms of the Creative Commons Attribution License 4.0 International License

\begin{abstract}
This study aimed to sort through loan words that entered into Turkish from foreign languages and that are used in the fields of literature, grammar, linguistics, and pedagogy, based on the latest edition of the Turkish Dictionary published by the Turkish Language Society in 2011. The study has a survey model, and the data were collected with a document-examination technique and presented in terms of percentage and frequency. As a result of the study, it was determined that the number of loan words used in the field of literature was 196, in the field of grammar was 102 , in the field of linguistics was 20, and in the field of pedagogy was 18 in Turkish. It was reported that Arabic was the language from which most words used in the fields of literature and grammar were borrowed and that French was the language from which most words used in the fields of linguistics and pedagogy were borrowed. It was seen that a vast majority of the loan words are nouns in the fields of literature, grammar, science, and pedagogy.
\end{abstract}

Keywords Turkish Dictionary, Loan Word, Literature, Grammar, Linguistics, Pedagogy

\section{Introduction}

Language is the most natural asset that enables communication between people. Language, described as the fundamental element of communication between people, is an instrument that allows for relations between different societies that come into contact with one another for various reasons. As a result of the relationships societies have with other societies, mutual interactions occur, and these interactions express themselves most clearly in a language. When language cannot cover a certain concept, object, or action, it consults with other languages, starting from those closest. Thus, word interchange takes place between the languages of different societies [1]. Özkan [2] specifies that it is possible to gather the causes that lead to interlinguistic interaction under two main headings, extra linguistic effects and language-dependent effects, and stated that a significant portion of extra linguistic effects emerge from social, political, and cultural relationships. These effects relay that the changes in the areas of religion and civilization between them; neighborly relations; migration; need-based relationships like education, information, culture, and technology interchange; economic-based connections like trade and tourism; areas of popular entertainment like music and sports; and psychological reasons like interest, curiosity, and pretension stand out. It is reported that linguistic factors can be ranked as the need for concept and term, the need for different and original expressions, artistic and literary flows, translations and alphabet changes.

Turkish is one of the languages that gives its own words to the languages of different societies and that assumes words from different societies into its own language. Turkish takes words from other languages similarly to how it has impacted other languages and given its words to the languages for centuries. Turkish, on the one hand, took words from eastern languages like Arabic throughout history while, on the other hand, it remained under the influence of western languages like Greek, Italian, Slavic, Romanian, Hungarian, French, German, and English [3]. In addition to this, many words taken from languages like Mongolian, Chinese, Sanskrit, and Sogdian are found in the works of the Old Turkish period [4]. It was seen that along with the Turks' accepting Islam, many words entered Turkish from Arabic and Farsi. Arabic, a language of religion and science, and Farsi, a literary language, greatly impacted Turkish [3]. It was seen that loan words from Farsi were not solely at the level of vocabulary and that suffixes, postpositions, and grammar were also assumed [1]. The entrance of these languages into Turkish and their influential settlement in the language continued until the 
1839 Reform movement. Along with the Ottoman State's pivot towards the west with the Reform movement, words from Western-origin languages, particularly French, began to situate themselves in the language. Almost all the words that Turkish has borrowed from western languages have been taken from French [5]. While Turkish-French relations, which were formalized legally, gained new speed together with the Reforms, schools were opened that provided education in foreign language, primarily French, and interest began to spike in French language and literature [6]. French was influential over Turkey Turkish, particularly in the words used in scientific, literary, technical, and philosophical areas [1]. With the declaration of the Republic in 1923, the Turkish language was dealt with as a state policy and the Language Revolution was realized. Although foreign words were planned to be removed from Turkish with the Linguistic Revolution, it set out to simplify the foreign words rather than remove them from the language. Turkish took words from German from World War I until the 1940s and then from English after World War II [4].

One of the resources that best shows the reflections of these loan words that enter into the language from other languages for various reasons is dictionaries. Dictionaries are "reference sources that record, explain, give examples with sentences chosen from literary texts, and note etymologies for all the words of a language or just in a certain period, in terms of writing, parts of speech, pronunciation, fundamental and side meanings, and properties of use." [7]. At the point of determining the words that Turkish has borrowed from other languages, the Turkish Dictionary has an important function. Eleven editions of the Turkish Dictionary have been printed by the Turkish Language Society, since its first edition in 1945. The Turkish Dictionary, which was most recently published in 2011, has a vocabulary of 122,423 words, terms, idioms and meanings of the words included in the dictionary. There is a total of 92,292 words found in the dictionary, including 77,005 lexical entries and 15,287 intermingled entries. Of these words, 53,451 are nouns, 12,666 are adjectives, 3,312 are adverbs, 88 are pronouns, 40 are postpositions, 299 are interjections, 50 are conjunctions, and 9,912 are verbs [7]. When considering the areas of use of the words, it is understood that the words are used in fields such as theology, philosophy, plant and animal sciences, astronomy, law, medicine, literature, navigation, music, cinema and theater, informatics, physics, chemistry, biology, and geography.

It is stated in the Dictionary that the number of loan words in Turkish is 15,391, and the numbers of loan words can be expressed as follows by language [7]:

According to Table 1, the first five languages from which Turkish borrows the most words are Arabic, French, Farsi, Italian, and English. It is determined that the number of loan words taken from these first five languages $(14,556)$ is $94.5 \%$ of the total number of borrowed words $(15,391)$.
Table 1. The numbers of loan words in the Turkish dictionary by language

\begin{tabular}{llll}
\hline Arabic & 6,516 & Hungarian & 15 \\
\hline French & 5,540 & Japanese & 13 \\
\hline Farsi & 1,375 & Mongolian & 12 \\
\hline Italian & 607 & Hebrew & 8 \\
\hline English & 518 & Finnish & 2 \\
\hline Romaic (Greek) & 448 & Malay & 2 \\
\hline German & 105 & Portuguese & 2 \\
\hline Latin & 68 & Sogdian & 2 \\
\hline Russian & 39 & Albanian & 1 \\
\hline Greek & 37 & Finnish & 1 \\
\hline Spanish & 31 & Korean & 1 \\
\hline Armenian & 24 & Serbian & 1 \\
\hline Bulgarian & 22 & Slavic & 1 \\
\hline
\end{tabular}

Turkish provided words to many other languages, which it has interacted with, just like it has taken words from different languages. For example, it was reported that close to 9,000 Turkish words passed into Serbian, about 3,500 words moved into Bulgarian, about 2,000 words entered into Arabic, about 2,000 into Farsi, more than 1,500 words passed into Russian, more than 1,000 into Hungarian, and more than 1,000 into Greek [7].

When reviewing the literature, it is seen that various studies regarding loan words entering into Turkish have been conducted [8,9,10,11,2,12,13,14,15,16,17,18,19]. A portion of the studies are comparative and classification studies relate to loan words from a certain language (Arabic, Farsi, French, etc.), to terms in a certain field (science, art, literature, etc.), to the appearances in various dictionaries of loan words, and to sound events seen in loan words. However, it was specified that loan words used in the fields of literature, grammar, linguistics, and pedagogy were discussed and that there were limited studies in which the parts of speech used were specified. For this reason, the study aimed to sort through loan words that entered into Turkish from foreign languages and that are used in the fields of literature, grammar, linguistics, and pedagogy, based on the latest edition of the Turkish Dictionary.

\section{Materials and Methods}

\subsection{Research Model}

The study is a survey-model, descriptive research. Survey models are research approaches that aim to describe in its existing form a current or past situation. The event, the individual, or the object that is aimed in the research study is defined just as it exists within its own conditions. The survey model is a kind of research study design which is conducted in order to come up with some general judgments about the population based on the whole 
population or a sample chosen from the population $[20$, 21].

\subsection{Working Group}

The latest edition of the Turkish Dictionary, published by the Turkish Language Society in 2011, comprises the working group for the research. The study attempted to scan the Turkish Dictionary and specify the loan words that entered into Turkish from foreign languages and that are used in the fields of literature, grammar, linguistics, and pedagogy.

\subsection{Data Collection and Analysis}

The research was structured using qualitative research methods and techniques. Qualitative research is defined as research in which data collection tools such as observation, interviews, and document analysis are used, and also in which a process is monitored to reveal realistically and integrally perceptions and events in a natural environment [22]. The research data were collected and analyzed using the document-examination technique, a qualitative research data-collection method. A document examination encompasses an analysis of the written materials that contain information about the case or cases targeted in the research. In this type of research, the researcher can use the needed data as a data-collection method in and of itself without having to conduct observations or interviews [22].

The latest edition of the Turkish Dictionary, published by the Turkish Language Society in 2011, was scanned page by page to collect the data for the research. As a result of the survey, the words borrowed from foreign languages were transferred to a computerized form prepared for the study. This form included the loan word, the language, and the part of speech of the borrowed word. Words, among which are words used in the fields of literature, grammar, linguistics, and pedagogy, and their parts of speech were transferred discretely into tables under four categories. The number of words was presented in terms of percentage and frequency, and they were interpreted and examples were provided for these words.

\section{Results}

\subsection{Findings Regarding Loan Words Used in Turkish Literature}

Table 2 provides findings related to the loan words used in the field of Turkish literature.
Table 2. Loan words and parts of speech used in Turkish literature

\begin{tabular}{lll}
\hline Language loaned from & f & \% \\
\hline Arabic & 127 & 64.8 \\
\hline French & 46 & 23.5 \\
\hline Farsi & 8 & 4.1 \\
\hline Arabic+ Farsi & 8 & 4.1 \\
\hline Farsi+ Arabic & 2 & 1 \\
\hline Turkish+ Arabic & 2 & 1 \\
\hline Turkish+ Farsi & 1 & 0.5 \\
\hline Italian & 1 & 0.5 \\
\hline Spanish & 1 & 0.5 \\
\hline TOTAL & $\mathbf{1 9 6}$ & $\mathbf{1 0 0}$ \\
\hline Parts of speech for loan words & $\mathbf{f}$ & $\mathbf{\%}$ \\
\hline Noun & 182 & 92.9 \\
\hline Adjective & 14 & 7.1 \\
\hline TOTAL & $\mathbf{1 9 6}$ & $\mathbf{1 0 0}$ \\
\hline
\end{tabular}

According to Table 2, the total number of loan words used in Turkish literature is 196. It is seen that the words that are used in the field of literature are mostly borrowed from the languages Arabic $(f: 127)$ and French $(f: 46)$. It is determined that the amount of the words borrowed from these two languages compared to the total number of words was $88.3 \%$. Farsi $(f: 8)$ follows these two languages. It was reported that words were borrowed from mixed words composed of the combination of two languages. The mixed words composed of the combination of Arabic and Farsi $(f: 8)$ words can be shown as an example for this situation. It was determined again that words used in the field of literature were borrowed from Italian $(f: 1)$ and Spanish $(f: 1)$. When studying the parts of speech of loan words, nouns $(f: 182)$ constitute a significant majority of the words and adjectives $(f: 14)$ constitute another. In other words, it can be said that the loan words used in the field of Turkish literature only constitute two parts of speech. Examples of loan words used in the field of Turkish literature are as follows:

Arabic: aruz [prosody] (noun), belagat [rhetoric] (noun), divan [council, parlor] (noun), fahriye (noun), hiciv [irony, satire] (noun), hüsnütalil (noun), iradımesel (noun), müstezat (noun), tenasüp [symmetry] (noun), zihaf (noun), manzum [poetic] (adjective), mukaffa [rhyming] (adjective), münşi (adjective), selis [fluent] (adjective)

French: alegori [allegory] (noun), anjanbuman [enjambment] (noun), epilog [epilogue] (noun), fabl [fable] (noun), ironi [irony] (noun), metafor [metaphor] (noun), parnasizm [Parnassianism] (noun) postmodernizm [postmodernism] (noun) sone [sonnet] (noun), apokaliptik [apocalyptic] (adjective), epik [epic] (adjective), pastoral (adjective) 
Farsi: bent [paragraph] (noun), efsane [legend] (noun), peşrev [prelude] (noun), şehname [Shahnameh] (noun)

Mixed: menakıpname (Arabic+ Farsi), terciibend (Arabic+ Farsi), türkü [poem] (Turkish+ Arabic)

Italian: tema [theme] Spanish: romans [romance]

\subsection{Findings Regarding Loan Words Used in Turkish Grammar}

Table 3 provides findings related to the loan words used in the field of Turkish grammar.

Table 3. Loan words and parts of speech used in Turkish grammar

\begin{tabular}{lll}
\hline Language loaned from & f & $\mathbf{\%}$ \\
\hline Arabic & 51 & 50 \\
\hline French & 46 & 45.3 \\
\hline German & 3 & 2.9 \\
\hline Farsi & 1 & 0.9 \\
\hline Russian & 1 & 0.9 \\
\hline TOTAL & $\mathbf{1 0 2}$ & $\mathbf{1 0 0}$ \\
\hline Parts of speech for loan words & $\mathbf{f}$ & $\mathbf{\%}$ \\
\hline Noun & 84 & 82.3 \\
\hline Adjective & 18 & 17.7 \\
\hline TOTAL & $\mathbf{1 0 2}$ & $\mathbf{1 0 0}$ \\
\hline
\end{tabular}

According to Table 3, the total number of loan words used in the field of Turkish grammar is 102. It is seen that the languages from which the field of grammar borrows words are Arabic $(f: 51)$ and French $(f: 46)$. It is determined that the amount of the words borrowed from these two languages compared to the total number of words was $95.3 \%$. German $(f: 3)$ follows these two languages. It was determined again that words used in the field of grammar were borrowed from Farsi $(f: 1)$ and Russian $(f: 1)$. When studying the parts of speech of loan words, nouns $(f: 84)$ constitute a significant majority of the words and adjectives $(f: 18)$ constitute another. In other words, it can be said that the loan words used in the field of Turkish grammar only constitute two parts of speech. Examples of loan words used in the field of Turkish grammar are as follows:

Arabic: cümle [sentence] (noun), edat [postposition] (noun), harfitarif [article] (noun), mazi [antecedent] (noun), nahiv [syntax] (noun), terkip [composition] (noun), yayınispi (noun), iltisaki [junction] (adjective), müennes [feminine gender] (adjective), müradif [synonymous] (adjective)

French: ablatif [ablative] (noun), apostrof [apostrophe] (noun), diftong [diphthong] (noun), haploloji [haplology] (noun), partisip [participle] (noun), fonolojik [phonological] (adjective), onomatopeik [onomatopoeic] (adjective), sinonim [synonymous] (adjective)

German: konsonant [consonant] (noun)

Farsi: sert [hard, harsh] (adjective)

Russian: şapka [hat] (noun)

\subsection{Findings Regarding Loan Words Used in Turkish Linguistics}

Table 4 provides findings related to the loan words used in the field of Turkish linguistics.

Table 4. Loan words and parts of speech used in Turkish linguistics

\begin{tabular}{lll}
\hline Language loaned from & f & $\mathbf{\%}$ \\
\hline French & 15 & 75 \\
\hline Arabic & 4 & 20 \\
\hline Farsi & 1 & 5 \\
\hline TOTAL & $\mathbf{2 0}$ & $\mathbf{1 0 0}$ \\
\hline Parts of speech for loan words & $\mathbf{f}$ & $\mathbf{\%}$ \\
\hline Noun & 18 & 90 \\
\hline Adjective & 2 & 10 \\
\hline TOTAL & $\mathbf{2 0}$ & $\mathbf{1 0 0}$ \\
\hline
\end{tabular}

According to Table 4, the total number of loan words used in the field of Turkish linguistics is 20 . It is seen that the languages from which the words used in the field of linguistics borrow are French $(f: 15)$ and Arabic $(f: 4)$. It is determined that the amount of the words borrowed from these two languages compared to the total number of words was $95 \%$. Farsi $(f: 1)$ follows these two languages. When studying the parts of speech of loan words, nouns $(f: 18)$ constitute a significant majority of the words and adjectives $(f: 2)$ constitute another. In other words, it can be said that the loan words used in the field of Turkish linguistics only constitute two parts of speech. Examples of loan words used in the field of Turkish linguistics are as follows:

French: artikülasyon [articulation] (noun), diyalekt [dialect] (noun), prozodi [prosody] (noun), pürizm [purism] (noun), valör [valor] (noun), diyalektolojik [dialectologic] (adjective)

Arabic: fehva [concept] (noun), lehçe [dialect] (noun)

Farsi: şive [accent] (noun)

Shared loan words were encountered in the fields of literature, grammar, and linguistics in Turkish. Three loan words used between literature and grammar (hece [syllable] Arabic noun, inşa [construction] Arabic noun, iştikak [etymology] Arabic noun) were identified. One loan word used between literature and linguistics (varyant [variant] French noun) was identified. And one loan word used between grammar and linguistics (kontekst [context] French noun) was identified.

\subsection{Findings Regarding Loan Words Used in Turkish Pedagogy}

Table 5 provides findings related to the loan words used in the field of Turkish pedagogy.

According to Table 5, the total number of loan words used in the field of Turkish pedagogy is 18. It is seen that the languages from which the words used in the field of pedagogy borrow are French $(f: 13)$ and Arabic (f:4). It is 
determined that the amount of the words borrowed from these two languages compared to the total number of words was $94.4 \%$. English $(f: 1)$ follows these two languages. When studying the parts of speech of loan words, nouns $(f: 17)$ constitute a significant majority of the words and adjectives $(f: 1)$ constitute another. In other words, it can be said that the loan words used in the field of Turkish pedagogy only constitute two parts of speech. Examples of loan words used in the field of Turkish pedagogy are as follows:

French: bakalorya [baccalaureate] (noun), formasyon [formation] (noun, kredi [credit] (noun), vize [visa] (noun)

Arabic: müfredat [syllabus] (noun), terbiyevi [educational] (adjective)

English: test (noun)

Table 5. Loan words and parts of speech used in Turkish pedagogy

\begin{tabular}{lll}
\hline Language loaned from & f & $\mathbf{\%}$ \\
\hline French & 13 & 72.2 \\
\hline Arabic & 4 & 22.2 \\
\hline English & 1 & 5.6 \\
\hline TOTAL & $\mathbf{1 8}$ & $\mathbf{1 0 0}$ \\
\hline Parts of speech for loan words & $\mathbf{f}$ & $\mathbf{\%}$ \\
\hline Noun & 17 & 94.4 \\
\hline Adjective & 1 & 5.6 \\
\hline TOTAL & $\mathbf{1 8}$ & $\mathbf{1 0 0}$ \\
\hline
\end{tabular}

\section{Discussion and Conclusions}

Turkish has taken words from many languages, just like it has given words to many languages with which it has a relationship for various reasons. According to the latest edition of the Turkish Dictionary printed in 2011, the number of words Turkish has borrowed from other languages is 15,391 . It is seen that a vast majority of these borrowed words passed into our language from Arabic, French, and Farsi. When considering the areas of use of the words, it is understood that the words are used in fields such as theology, philosophy, plant and animal sciences, astronomy, law, medicine, literature, navigation, music, cinema and theater, informatics, physics, chemistry, biology, and geography. In the lexicological study that Ersoy [13] conducted on the topic of information about the areas of use of foreign vocabulary in Turkish, it was observed that Turkish borrows words related to science heavily from other languages, that the borrowed words relating to science and those regarding the fields of science and nature were taken significantly from western languages and French in particular, and that words related to social fields were taken heavily from eastern languages like Arabic and Farsi. When considering loan words in terms of parts of speech, it is determined that the words mostly consist of parts of speech like nouns, adjectives, verbs, and adverbs.
It was determined that the total number of loan words in Turkish literature, grammar, linguistics, and pedagogy was 336 in this study, which examined the loan words used in each of these four fields. It is thought that there is a total of 15,391 words in the Turkish Dictionary that are borrowed from foreign languages, this means that the amount of loan words that are used in these four areas compared to the total number of loan words is about $2.18 \%$. It was determined that the number of loan words used in the field of literature was 196, in the field of grammar was 102, in the field of linguistics was 20 , and in the field of pedagogy was 18 in Turkish.

The findings indicated that French and Arabic are the two languages from which the words utilized in the field of Literature and Grammar were borrowed. In addition, Farsi follows these two languages in the field of literature. German was another language that contributed to Turkish grammar after French and Arabic. Furthermore, the findings showed that only one word was borrowed from Italian and Spanish in the field of literature. Likewise, Russian and Farsi contributed to Turkish grammar with one word. It was also identified that the languages that influenced the fields of Linguistics and Pedagogy in Turkish were French and Arabic, respectively. Whereas these two languages were followed by Farsi in the field of linguistics, they were followed by English in educational sciences. When the parts of speech of loan words were explored, nouns and adjectives constitute a significant majority of the borrowed words in Turkish.

It was seen that a significant portion of the loan words used in the areas of literature, grammar, linguistics, and pedagogy were taken from Arabic and French. Mengi [23] explains the change and diversity of words, concepts, and terms used in the field of literature as follows: We said that the literary terms we use today, the Turkish ones, came first from the East (Arabic) and later from various Western-origin languages. A portion of the Western-origin words, most of which are French, began to be used in the place of Ottoman terms after they entered into our vernacular; Thus, some of the old terms lost their importance in use over time." The most important reason for loan words used in the field of literature coming from Arabic and French is that these words are nourished by three main sources. The first of these sources are Turkish words like koşuk, sagu, and sav [verse, sago, assertion] from the first of these sources and that were used in the pre-Islamic period. The second of these sources is words are taken from Arabic and French and shaped like gazel, kaside, terkib-i bend, efsane, and destane [lyric, eulogy, composition, legend, and myth] that are particularly referred to in Ottoman as "istrlahat-1 edebiyye" [scientific literature] and found in the body of Classical Turkish Literature. And the third of these sources is words like classism, realism, ideal, and eclogue that have passed from French to Turkish as of the Reform Period with Turkish literature developing in under the influence of the West 
[24].

Just like this study, in which loan words used in the fields of literature, grammar, linguistics, and pedagogy are examined from various perspective, it is recommended that new comparative studies need to be conducted using different perspectives and resources relating to the loan words used in other areas of Turkish. Thus, it is thought that the mutual interaction among languages could be revealed through concrete data.

\section{REFERENCES}

[1] O. Durmuş. Alıntı kelimeler bakımından Türkçe sözlük, A. Ü. Türkiyat Araştırmaları Enstitüsü Dergisi, 26, 1-21, 2004 , Doi:http://dx.doi.org/10.14222/Turkiyat586

[2] N. Özkan. Türkçedeki yabancı unsurları tasnif denemesi, 38. ICANAS Bildiriler Dil Bilimi, Dil Bilgisi ve Dil Eğitimi, III. Cilt, 1343-1359, Atatürk Kültür Dil ve Tarih Yüksek Kurumu Yayınları, Ankara, 2011.

[3] Z. Korkmaz. Türkiye Türkçesinde yazı diline girmiş günlük yaşamla ilgili alıntı sözler ve ekler, Türk Dili, 620, 118-127, 2003.

[4] A. Gözütok. Türkiye Türkçesinde karma kelimeler, A. Ü. Türkiyat Araştırmaları Enstitüsü Dergisi, 36, 17-22, 2008. DOI :http://dx.doi.org/10.14222/Turkiyat747

[5] G. Karaağaç. Türkçenin alıntılar sözlüğü, Akçağ Yayınları, Ankara, 2015.

[6] A. Çiçek. Türkçeye giren Fransızca kökenli bazı kelimeler üzerine bir inceleme, A. Ü. Türkiyat Araştırmaları Enstitüsü Dergisi, 24, 1-9, 2004, Doi:http://dx.doi.org/10.14222/Tur kiyat5 15

[7] TDK Türkçe sözlük, Türk Dil Kurumu Yayınları, Ankara, 2011.

[8] A. Aktaş. Türkçede Almanca kaynaklı kelimeler, Türk Dili, 666, 522-528, 2007.

[9] İ. Magrelo. Türkçede batı kökenli yabancı sözcükler, Uluslararası Sosyal ve Ekonomik Bilimler Dergisi, 1(1), 7-10, 2011.

[10] H. Dursunoğlu. Türkiye Türkçesi’ndeki Arapça sözcükler ve bu sözcüklerdeki ses olayları, 38. ICANAS Bildiriler Dil Bilimi, Dil Bilgisi ve Dil Eğitimi, I. Cilt, 517-528, Atatürk Kültür Dil ve Tarih Yüksek Kurumu Yayınları, Ankara, 2011.

[11] F. Erbay. Türkçe Sözlük'ün ilk ve son baskısındaki batı kökenli kelimelere dair, Selçuk Üniversitesi Türkiyat Araştırmaları Dergisi, 11, 129-135, 2002.

[12] P. Seçkin, A. M. Coşar. Türkçede alıntılardan kelime türetmede kullanılan ekler, Uluslararası Türkçe Edebiyat Kültür Eğitim Dergisi, 6(3), 1398-1442, 2017. http://dx.doi.org/10.7884/teke.3972

[13] H. Ersoy. Türkçedeki yabancı sözcüklerin kullanım alanı bilgileri ve düşündürdükleri (sözlükbilimsel bir çalışma), Akademik İncelemeler Dergisi, 1(2), 205-219, 2006.
[14] F. Korkmaz. Alıntı kelimelerin Türkçeleşme sürecinde bazı Arapça kelimelerin görev değişikliğine uğraması üzerine, İlmî Araştırmalar, 23, 103-112, 2007.

[15] V. Ülkü. Türkçenin zenginleştirilmesi, Dil ve Edebiyat Dergisi, 3(1), 25-33, 2006.

[16] İ. Erdem. Konuşma dili açısından Arapça ve Farsça alıntı kelimelerin bugünkü durumu, Ana Dili Eğitimi Dergisi, 1(1), 92-100, 2013. DOI: 10.16916/aded.16022

[17] O. Ergene. Alıntı sözcükler için verilen kaynak dil ve özgün biçim bilgileri açısından Türkçe sözlüklerin karşılaştırılması, Turkish Studies, 9(3), 647-674, 2014. Doi:10.7827/TurkishStudies.6110

[18] H. Dursunoğlu. Türkiye Türkçesindeki Farsça sözcükler ve kullanım şekilleri, Atatürk Üniversitesi Sosyal Bilimler Enstitüsü Dergisi, 13(1), 131-142, 2009.

[19] V. İ. Karaca. Türkiye Türkçesindeki alıntı sözcüklerde görülen ses olayları üzerine bir inceleme, Turkish Studies, 7(4), 2059-2090, 2012. DOI:10.7827/TurkishStudies.4107

[20] N. Karasar. Bilimsel araştırma yöntemi, Nobel Yayınları, Ankara, 2006.

[21] Ş. Büyüköztürk, E. K. Çakmak, Ö. E. Akgün, Ş. Karadeniz, F. Demirel. Bilimsel araştırma yöntemleri, Pegem Yayıncılık, Ankara, 2014.

[22] A. Yıldırım, H. Şimşek. Sosyal bilimlerde nitel araştırma yöntemleri, Seçkin Yayıncılık, Ankara, 2006.

[23] M. Mengi. Divan şairinin dilindeki edebiyat terimleri, I. Balıkesir Kültür Araştırmaları Sempozyumu, 1-2 Haziran, Balıkesir, 1998.

[24] M. Naci. Istılâhât-1 edebiyye, Şirket-i Mürettibiyye Matbaası, İstanbul, 1890. 